\title{
Spray Drying Encapsulation of Probiotics for Functional Food Formulation-A Review
}

ISSN: 2640-9208

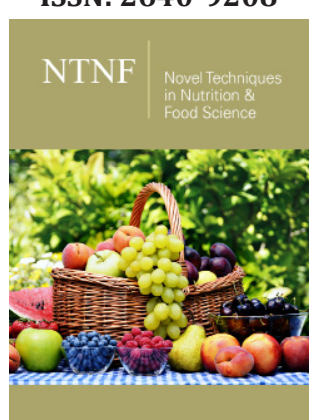

*Corresponding author: Sarkar S Department of Quality Assurance, Keventer Agro Limited BarrackporeBarasat Link Road, Subashnagar, P.O. Neelgunj Bazar, Kolkata-700121, West Bengal, India.

E Mail: drsurajitsarkar@yahoo.co.in

Submission: 侮 May 16, 2020

Published: 漹 October 09, 2020

Volume 5 - Issue 2

How to cite this article: Sarkar S. Spray Drying Encapsulation of Probiotics for Functional Food Formulation-A Review. Nov Tech Nutri Food Sci. 5(2). NTNF. 000610. 2020

DOI: 10.31031/NTNF.2020.05.000610

Copyright@ Sarkar S. This article is distributed under the terms of the Creative Commons Attribution 4.0 International License, which permits unrestricted use and redistribution provided that the original author and source are credited.

\section{Sarkar S*}

Department of Quality Assurance, Keventer Agro Limited Barrackpore-Barasat Link Road, Subashnagar, P.O. Neelgunj Bazar, Kolkata-700121, West Bengal, India.

\begin{abstract}
Health consciousness coupled with enhanced health care cost has led consumer's inclination towards functional foods. Documented health benefits have projected probiotics as a new functional ingredient in the current era of self-care and complementary medicine. It has been established that the probiotic viability is necessary for the exhibition of health benefits but is lost during processing, storage and gastrointestinal transit. Probiotic viability can be retained with the adoption of spray drying encapsulation technique and better survival of the encapsulated probiotics than the free cells in the food matrix have been reported. Major challenges faced during the encapsulation of probiotic by spray drying are modulation of processing parameter, selection of probiotic strains and coating materials and stability during gastric transit. Proper selection of probiotic strains and cell wall materials, modulation of technological parameters of spray drying and storage conditions would yield spray dried encapsulated probiotics with greater viability. Spray dried encapsulated probiotics had higher viability than free cells and its supplementation may be a practical alternative for better retention of viability and functionality of probiotics during the formulation of functional foods.
\end{abstract}

Keywords: Functional food; Health benefits; Microencapsulation; Probiotic; Spray drying encapsulation

\section{Introduction}

Globally, consumer's inclination towards health promoting foods has led to development of functional foods due to health deterioration, busy lifestyles, low consumption of convenience foods and insufficient exercise, increased incidence of self-medication, increased awareness of the link between diet and health [1]. Although functional foods lack a standard definition [2], but the production and consumption of functional foods has increased due to their capabilities of providing health benefits beyond basic nutrition [1], meeting the needs of the aging population and to cope with the rising costs of health care [3]. Documented health benefits of probiotics [4] and their capability to colonize gut [5] have projected probiotics as a new functional ingredient. Functional foods containing probiotic bacteria are gaining popularity in the global market [6,7], especially in Japan, Europe and the United States [8]. It has been established that survival of probiotics in the harsh acidic conditions during gastric transit and reaching the large intestine in an adequate amount for colonization and proliferation are prerequisites for exhibiting health benefits [9]. Therefore, retention of probiotic viability in the food matrix during processing, subsequent storage as well as during gastric transit are key issues during formulation of functional foods.

Microencapsulation is defined as "the technology of packaging of solid, liquid or gaseous materials miniaturized in capsules that can release their contents in a controlled manner and only under certain conditions". Microencapsulation has emerged as an alternative technology for the protection of probiotic bacteria from adverse environments [10], resisting processing and packaging conditions, improving taste, aroma, stability, nutritional value and product appearance [11]. Furtherer, microencapsulation also allows controlled release of functional components at targeted sites and masks unpleasant taste and odour of the substances [12]. Desai et al. [13] reported the following reasons for adoption of microencapsulation process in the food industry: 
a) Protection of the core material from degradation by reducing its reactivity to its outside environment

b) Reduction of the evaporation or transfer rate of the core material to the outside environment

c) Modification of the physical characteristics of the original material to allow easier handling

d) Tailoring the release of the core material slowly over time or at a particular time

e) To mask an unwanted flavors or taste of the core material

f) Dilution of the core material when only small amounts are required, while achieving uniform dispersion in the host material

g) To help separate the components of the mixture that would otherwise react with one another.

Microencapsulation of probiotics can be done by employing various encapsulation techniques, but spray drying is widely adopted by the food industries during the development of functional foods. In the present paper an attempt has been made to highlight potentiality of spray drying technique for probiotic encapsulation and their subsequent application for functional food formulation.

\section{Modulation of gut flora by probiotics}

Human intestine is sterile at birth and is subsequently seeded with microorganisms due to swallowing of colonized amniotic fluid [14] and from various sources such as environment, maternal vagina and faeces $[15,16]$. Early colonization and balance between commensal and pathogenic bacteria is of utmost importance for normal function, immunology and homeostasis in the healthy intestine and any disruption of this balance may lead to disease conditions [17] such as allergies, obesity and diabetes [18]. Beneficial microbes capable of colonizing the gut regulate overall health of humans by restructuring the gut microbial balance [19]. Diversity in microflora of gastrointestinal tract of humans during different stages of life have been noted (Table 1) and modulation of the gut flora with suitable probiotic formulations may be a practical solution for maintaining good health.

Table 1: Diversity in microflora of GIT.

\begin{tabular}{|c|c|c|}
\hline $\begin{array}{l}\text { Stages of life/ } \\
\text { Human conditions }\end{array}$ & Constituting Predominant Microflora & References \\
\hline Normal infants & $\begin{array}{c}\text { Bifidobacterium, Lactobacillus, } \\
\text { Bacteroides }\end{array}$ & $\begin{array}{l}\text { Penders et al. [112] } \\
\text { Stenger et al. [116] }\end{array}$ \\
\hline \multirow{2}{*}{ Preterm infants } & Enterobacteriaceae, Clostridium & $\begin{array}{l}\text { Patel \& Denning [111] } \\
\text { Jakaitis \& Denning [110] }\end{array}$ \\
\hline & Staphylococcus aureus, Klebsiella & Gewold et al. [106] \\
\hline Vaginally delivered infants & $\begin{array}{l}\text { Bifidobacterium longum, } \\
\text { Bifidobacterium catenulatum }\end{array}$ & Biasucci et al. [105] \\
\hline \multirow{2}{*}{ Cesarean delivered infants } & No bifidobacteria & Biasucci et al. [105] \\
\hline & Low Bacteroides fragilis & Gronlund et al. [107] \\
\hline After first week & Bifidobacterium, Lactobacillus & Balamurugan et al. [103] \\
\hline Upper portion of the colon & $\begin{array}{l}\text { Enterobacter, Streptococci, } \\
\text { Staphylococci, Lactobacilli, } \\
\text { Propionibacterium, Bacilli }\end{array}$ & \multirow{2}{*}{ Steer et al. [115] } \\
\hline Lower portion of colon & $\begin{array}{c}\text { Bacteroides, Bifidobacterium, } \\
\text { Eubacteria, Peptococci, } \\
\text { Fusobacterium, Clostridium }\end{array}$ & \\
\hline $\begin{array}{l}\text { Centre of lumen } \\
\text { and epithelial surface }\end{array}$ & Bacteroides, Bifidobacterium & Sullivan et al. [117] \\
\hline Breast-fed infants & Lactobacilli, Bifidobacteria & Harmsen et al. [109] \\
\hline $\begin{array}{l}\text { Breast-fed infants } \\
\text { (After } 5 \text { days) }\end{array}$ & B.catenulatum & Guemonde et al. [108] \\
\hline \multirow{3}{*}{$\begin{array}{l}\text { Breast-fed infants } \\
\text { (After } 3 \text { weeks) }\end{array}$} & B. longum & Guemonde et al. [108] \\
\hline & Bifidobacterium bifidum & Yuhara et al. [122] \\
\hline & Bifidobacterium breve, B. longum & Benno et al. [104] \\
\hline \multirow{2}{*}{ Formula-fed infant } & $\begin{array}{l}\text { Bacteroides, Clostridium, } \\
\text { Enterobacteriaceae }\end{array}$ & Harmsen et al. [109] \\
\hline & $\begin{array}{c}\text { Enterobacteriaceae, Enterococci, } \\
\text { Bacteroides }\end{array}$ & Rodriguez et al. [113] \\
\hline
\end{tabular}




\begin{tabular}{|c|c|c|}
\hline $\begin{array}{c}\text { Formula-fed infant } \\
\text { (After 7 days) }\end{array}$ & Bacteroides fragilis & Yoshioka et al. [121] \\
\hline After weaning & Bacteroides, Prevotella, Ruminococcus, Clostridium, Veillonella & Valles et al. [119] \\
\hline Adult & $\begin{array}{c}\text { Bifidobacterium, Clostridium, Bacteroides, Eubacterium, Escherichia, } \\
\text { Enterococcus, Streptococcus, Klebsiella }\end{array}$ & $\begin{array}{c}\text { Shanahan [114] } \\
\text { Vasiljevic \& Shah [120] }\end{array}$ \\
\hline
\end{tabular}

Probiotics are live microorganisms which when administered in adequate amounts confers health benefits to the host [20]. Reviewed literature indicated link between probiotics and health [4,21-23] and probiotics confer diverse human health benefits such as normalization of the intestinal flora, anti-carcinogenesis, hypocholesterolemic effect, alleviation of lactose malabsorption, allergy [4], enhance the immune system [24] and prevention of antibiotic-associated diarrhoea [25]. Recently, [26] declared that probiotics can affect the gut composition and their metabolic functions through gastrointestinal pathways or modulation of the gut bacterial community. Rolfe [27] declared following mechanisms by which probiotics exert health benefits.
a) Production of inhibitory substances against pathogens
b) Blocking of pathogenic bacteria adhesion sites
c) Nutrient competition and production
d) Degradation of toxins and toxin receptors
e) Modulation of immune responses

For exerting health benefits, viable probiotics must be consumed at a higher concentration and must be stable during its transit through the gastrointestinal tract. According to International Dairy Foods Association, viable probiotic cells in any probiotic product should be more than $10^{7} \mathrm{cfu} / \mathrm{g}$ up to the date of minimum durability [28] and daily intake (cfu/g) dosages should be $10^{8}[29],>10^{8}-10^{10}$ [30] or $10^{8}-10^{9}$ [31]. Karimi et al. [32] suggested daily intake of an approximately $100 \mathrm{~g}$ of probiotic products to ensure $10^{9}$ viable cells into the intestine. It can thus be concluded that probiotics must survive in sufficient quantities in the functional foods and must be ingested at sufficient quantity for exhibition of its functional properties.

\section{Microencapsulation techniques}

Encapsulation can be done by different techniques such as extrusion, emulsion, fluid bed, rennet-gelled protein encapsulation, freeze drying and spray drying. Tyagi et al. [33] classified microencapsulation techniques into three groups.

a) Physical methods such as spray drying, lyophilization, supercritical fluid precipitation and solvent evaporation

b) Physico-chemical methods including coacervation, liposomes and ionic gelation

c) Chemical methods such as interfacial polymerization and molecular inclusion complexation.

Amongst various encapsulating techniques, freeze drying, and spray drying are commercially widely adopted [34]. Application of encapsulated probiotics obtained with the freeze drying or spray drying extend certain advantages in terms of a relatively long shelf life, stable quality control and convenience in handling, transportation and storage [35,36]. Spray-drying method is considered better than extrusion or emulsion methods due to production of stable micro-particles with low diameters and homogenous size distribution [37-39]. Encapsulation by Freeze drying may be the preferred over spray drying due to less viability losses (4-27.5\% vs. 19-40\%) of Bacillus coagulans [40].

In freeze-drying, initially water in the foodstuffs is frozen [41], followed by the removal of frozen water through the sublimation process. It has been noted that crystal formation and stress condition by high osmolarity during freezing causes damage of cell membrane to leak the intracellular substances and requires addition of cryoprotectants prior to fermentation to assist in the adaptation of probiotics to the environment [42].

Spray drying process involves passage of foodstuffs through a nozzle to form droplets in the drying chamber, where the droplets are dried immediately when they come in contact with hot air to form powder [43]. Spray drying method is preferred over freeze drying as the former method is faster (30 minutes) than the latter method (72 hours). Dehydration has adverse effects on cell membranes and secondary protein structures and freeze-drying generally has less impact on the viability than the harsher processing conditions of spray-drying $[44,45]$. However, encapsulation by spray drying is the predominant technique adopted by dairy industries as the cost of spray drying is six times less than freeze-drying for removal of per kilogram of water [46] and can be stored for longer period at lower cost [47]. Zuidam \& Shimoni [48] denoted that selection of encapsulation technologies should be based on certain considerations such as effect of processing on probiotics viability, processing conditions employed during food production or processing, storage conditions of the food product containing the encapsulated bacteria prior to consumer use, particle size and density required for incorporation encapsulated bacteria into the food product, mechanisms of release and the cost constraints.

\section{Factors affecting efficacy of encapsulation}

Microencapsulation of bacteria in polymeric and biodegradable matrix is done for retention of the viability of the probiotic strains under the harsh conditions of food product preparations coupled with efficient delivery of probiotic strains to the intestine [49]. Diverse factors affecting efficacy of microencapsulation are enumerated below.

Type of solvent used

a) Strains of lactic acid bacterial employed 
b) Composition of encapsulation material [50]

c) Drying conditions such as inlet and outlet temperatures, flow rate and humidity of drying gas, feed flow rate, pressure and speed of atomizer [51]

d) Storage temperature [52]

e) Viscosity, solids content and surface tension of feed formulation [51]

\section{Basic principle of Spray drying encapsulation}

Basic principle involved in the spray drying includes the atomization of cells in a polymer solution into a drying chamber through atomizer, drying of liquid droplets inside the drying chamber [53], which leads to solvent evaporation and formation of the microcapsules [54] and recovery of powder through a cyclone separator [55]. Schafroth et al. [56] declared that spray drying technique comprises of three stages (i) Homogenization of the feed liquid by an atomizer (ii) Drying of the feed solution by a hot gas carrier to achieve the evaporation of the solvent (iii) Collection of the dry particles by cyclones or a filter. Recently, Broeckx et al. [57] divide the spray drying process in four stages.

a) Liquid feed is atomized into a spray of little droplets

b) Atomized spray comes in contact with a heated gas in the drying chamber

c) Drying of the droplets and the particle formation

d) Solid particles are separated from the drying air

Feed samples intended for spray drying encapsulation are prepared by dissolving the core materials in a single or a combination of carrier materials with the objective of forming an emulsion or a suspension. Afterwards mixing of core compounds and carrier materials is performed through high-speed mixing or high-shear emulsification to form a coarse emulsion. Commonly used carrier materials in spray drying are hydrophilic polysaccharides such as maltodextrins, chitosan, alginate and different types of gums and proteins like whey protein), whereas the core materials can be active hydrophobic or hydrophilic molecules [58,59]. Huang et al. [36] declared that for optimization of probiotics encapsulation by spray drying, following stages should be considered.
1) Pre-drying
2) During spray drying
3) Post-drying

\section{Advantages of Spray drying encapsulation}

Spray drying is most widely used by industries for encapsulation of food bioactive compounds owing to following reasons.

1) It is an economical technique due to high production rate with minimum operating costs $[60,61]$

2) Highly suitable for heat sensitive compounds as total drying time is few milliseconds to few seconds $[62,63]$
3) Higher stability, lower storage and transport costs and easier usage [51]

4) Diameter of the spray dried microcapsules generally ranges between 5 to $100 \mu \mathrm{m}[64,65]$, which facilitates a greater contact surface for the nutrient's availability [66] without affecting the palatability of microencapsulated incorporated food products [67]

5) Protection of microencapsulated cells from bacteriophages and detrimental factors such freeze drying, freezing and storage, thereby retaining higher viability [68]

6) Homogeneous distribution throughout the product due to conversion in powdered form [68]

\section{Challenges of encapsulation of probiotic by Spray drying}

Owing to certain advantages of low cost, high productivity and rapid processing, spray drying is one of the most commonly used microencapsulation technologies within the food industry and has emerged as the most promising technique for retention of probiotic viability but also has few challenges.

\section{Modulation of processing parameter}

Heat, osmotic, oxidative and desiccation stresses are usually considered to be the main mechanisms which cause the inactivation of bacteria during and after spray-drying [69]. Higher temperature during spray drying results in the formation of cellular pores and leakage of the intracellular substances [42]. Spray drying at higher outlet temperature induced greater viability losses due to more dehydration resulting from greater exposure of micro-particles at higher temperature [70]. On the other hand, lowering of inlet temperature results in higher post-encapsulation viability but greater moisture and water activity adversely affects the prolonged storage [71-73] reported that loss of viability of L. plantarum WCFS1 during drying is due to dehydration inactivation, thermal inactivation or a combination of both types of inactivation. Adoption of suitable protectants during spray drying conferred protection to the encapsulated cells [74,75], which can be attributed to mechanisms of enhancing the intrinsic stress tolerance of probiotic cells, providing extracellular protection on cells as physical shield and having favorable drying kinetics [76]. Additional thermo-protection can be achieved through the addition of free radical scavengers or by reducing water mobility through the cell membranes and the cell wall thus modulating dehydration upon heating [77]. Considerations should be given to pre-drying, during spray drying and post-drying [36] for retaining the viability of encapsulated probiotics at recommended level [31].

Protection conferred to probiotics is also dependent on the size of encapsulated cells. Larger microcapsules provide better protection to probiotics than smaller capsules but are poorly dispersed and impart sandiness in foods. On the other hand, microencapsules with size below $1 \mathrm{~mm}$ result in mechanical instability during prolonged fermentation. Optimum size of capsules should range between 1 to $3 \mathrm{~mm}$ [78] to satisfy the requirements of cell growth and provide 
mechanical strength to the capsule. Considerations should be given to control the conditions leading to microcapsules of optimum size

\section{Selection of probiotic strains}

All probiotics are not equally capable of withstanding the processing or storage conditions. During spray drying variability in thermal resistance were noted amongst Bifidobacterium Bb12, Lactobacillus acidophilus La-5 and Propionibacterium jansenii 702 [79,80]. Spray drying leads to increased cell permeability by affecting the cell membrane, causing loss of intracellular components from the cell into the surrounding environment [31]. High or low temperatures and/or the use of organic solvents are detrimental for the viability of the probiotic cultures [78]. Considerations should be given to avoid loss of the internal components of the cell due to increase in the cell permeability of probiotics [81]. Rodrigues et al. [82] noted greater storage stability of whey protein-based microcapsules of $L b$. paracasei than $B$. animalis $\mathrm{Bb} 12$ and $L b$. acidophilus. Selection of suitable bacterial strains that can withstand osmotic stress, drying conditions and desiccation must be considered [51].

\section{Selection of coating materials}

Viability of probiotics during encapsulation by spray drying is also influenced by the type of core material employed. Complete loss of viability of Lactobacillus zeae LB1 was encountered during spray drying employing water without any wall material [83]. Scanning electron microscopy of spray dried microparticles of Lactobacillus acidophilus La-5 $(4.85 \mu \mathrm{m})$ and Bifidobacterium Bb$12(8.75 \mu \mathrm{m})$ revealed high porosity and ruptures in their structure, which may be related to the low solids concentration $(12 \% \mathrm{~m} / \mathrm{v})$ used in the formulations $[64,84]$. Earlier single polymer formula was used to encapsulate probiotic cells using spray drying but adoption of binary systems extended advantages in terms of higher encapsulation efficiencies and/or higher survival rates, superior in vitro gastrointestinal digestion and storage properties [85]. Further, coating material like chitosan is reported to exhibit antimicrobial activity and therefore it becomes necessary to use other coating materials as co-protectors or a two-step microencapsulation $[7,86,87]$. A combination of different coating materials has been suggested as application of a single material does not satisfy all desired requirements [13]. Selection of the coating material should be based on the physicochemical properties, solubility, viscosity in the prepared solution, the compatibility with the core-material and the intended size and surface of the final microcapsules [88].

\section{Stability during gastric transit}

During gastric transit, probiotics are adversely affected by the enzymatic action of pepsin, low $\mathrm{pH}$ of the stomach and antagonism associated with antimicrobial activity of bile salts and protease-rich conditions of the intestine $[31,89]$. Spray dried microcapsules are water soluble, resulting in an early release of the cells at an undesired site or time, thus probiotic bacteria are not protected from adverse conditions of storage and gastrointestinal transit [90]. Stability of microencapsulated probiotics in fermented milks and efficacy of microencapsulation to deliver probiotics in the gastrointestinal tract is challenging [91]. Considerations should be given so that encapsulated probiotics are released in the gut microenvironment due to changes in $\mathrm{pH}$, enzymatic activity or osmotic strength to foster their colonization in the intestine [78,92]. Type of the wall material and atomization method employed during spray drying also influence the stability of encapsulated probiotics in simulated gastrointestinal tests. During simulated gastrointestinal tests, significantly higher viability of microencapsulated Bifidobacterium infants was reported with use of whey protein concentrate and twofluid nozzle than that those employing soy protein concentrate and spray centrifugal atomizer [93].

\section{Functional properties of spray-dried probiotics}

Probiotics are incorporated during fermented milk formulations with the objective of enhancing its functional properties. Probiotics are generally introduced in fermented milk in non-capsulated form and viability of probiotics is influenced by the food matrix, associated metabolic behavior with other starter cultures, strains of probiotic cultures employed, processing and storage conditions.

Preserving the efficacy of probiotic bacteria represents the most challenging during the development of functional food products. Jantzen et al. [94] noted decline in counts of Lactobacillus reuteri after drying ( 2 log cycles) as well as after 4 weeks of storage (1 log cycle) but survival rate of encapsulated bacteria was $32 \%$ higher compared with non-encapsulated when exposed to artificial digestive juice. Spray drying of L. casei in presence of using vegetable extracts and maltodextrin induced only one log cycle reduction in viable counts but retained its viability at a level of $>10^{7} \mathrm{cfu} / \mathrm{g}$ of $L$. casei after 60 days of storage and can be used for the development of functional food [65]. In another investigation, Ivanovska et al. [95] noted that synbiotic spray dried micro-particles of Lactobacillus casei obtained employing, sodium alginate, chitosan and fructo-oligosaccharide retained viability above the minimum therapeutic during incubation of $24 \mathrm{~h}$ in simulated gastrointestinal conditions $(7.67 \pm 0.4 \mathrm{log} \mathrm{cfu} / \mathrm{g})$ as well as after 3 months of cold storage $(8.1 \pm 0.6 \log \mathrm{cfu} / \mathrm{g})$. Maciel et al. [96] also encountered higher storage stability of spray dried encapsulated $L b$. acidophilus La-5 in sweet whey with an average decrease of only $0.43 \mathrm{log} \mathrm{cfu} / \mathrm{g}$ at the end of 90 days of storage and retained viability above 6 log $\mathrm{cfu} / \mathrm{g}$. Significantly higher viable counts of encapsulated B. breve in comparison to free cells were encountered in yoghurt supplemented with whey protein encapsulated $B$. breve $\left(6-7 \times 10^{6} \mathrm{cfu} / \mathrm{ml}\right)$ and B. longum $\left(5-6 \times 10^{7} \mathrm{cfu} / \mathrm{ml}\right)$ after 28 days of storage at $4{ }^{\circ} \mathrm{C}$ [38]. Recently, Fazilah et al. [97] also encountered higher viability (cfu/ $\mathrm{ml}$ ) of spray dried microencapsulated Lactococcus lactis ( $\sim 10^{7} \mathrm{vs.}$ $\sim 10^{5}$ ) in yogurt in comparison to non-microencapsulated cells.

Spray drying has emerged as an effective way to produce encapsulated probiotics with high survival rates and improved resistance during gastric transit [98,99]. Among four stains better survival $(\log \mathrm{cfu} / \mathrm{ml})$ of spray dried encapsulated Lactobacillus casei subsp L. rhamnosus TISTR 047 (8.31 \pm 0.11 vs. $4.06 \pm 0.08$ ) in comparison to non-encapsulated cells was encountered [100]. A double blind, randomized, cross-over study revealed no difference in kinetics of intestinal colonization in healthy volunteers receiving 
non-encapsulater or encapsulated probiotic strains of Lactobacillus plantarum LP01 and Bifidobacterium breve BR03 after 21 days of feeding [101]. Further it was reported that functional properties of probiotics are not affected by spray dried encapsulation. Burns et al. [102] reported that the anti-inflammatory capacities of both isolated Bifidobacterium animalis subsp. lactis INL1 and commercial strain B. animalis subsp. lactis BB12 were not affected by spraydrying [103-122].

\section{Conclusion}

Potential health and nutritional benefits of probiotics have boosted the demand for functional probiotic foods in the current era of self-care and complementary medicine. It has been established that viability of probiotics is of utmost importance for extending health benefits and must be consumed in sufficient quantity. Probiotic viability may be lost during processing, storage and gastric transit and therefore retention of viability of probiotics during formulation of probiotic functional foods are challenging. Encapsulation of probiotics has emerged as the most promising technique for retention of probiotic viability. Amongst different techniques, spray drying is most commonly commercially adopted encapsulation technique for preservation of probiotic viability. Major challenges faced during encapsulation of probiotics by spray drying are modulation of processing parameters, selection of probiotic strains and coating materials and stability during gastric transit. Heat, osmotic, oxidative and desiccation stresses are usually considered to be the main mechanisms which cause the inactivation of bacteria during and after spray-drying. Higher viability in spray dried encapsulated probiotics could be achieved by proper selection of probiotic cultures, wall materials, controlling pre-drying, drying and post-drying conditions and storage. Spray dried encapsulated probiotics have great potential for formulation of functional foods and its commercial application would benefit both industries and consumers.

\section{References}

1. Corbo MR, Bevilacqua A, Petruzzi L, Casanova FP, Sinigaglia M (2014) Functional beverages: the emerging side of functional foods. Compreh Rev Fd Sci Fd Safety 13(6): 1192-1206.

2. Hasnah S, Ameira Y (2010) Malaysian consumer knowledge and preferred information sources in selecting functional foods. J Agribusiness Marketing 3: 20-39.

3. Reinhardt W, Rahavi E, Childs N, White C (2011) Functional foods: consumer attitudes, perceptions, and behaviors in a growing market. Am Diet Assoc 111(6): 804-810.

4. Sarkar S (2013) Probiotics as functional foods: documented health benefits. Nutr Fd Sci 43(2): 107-115.

5. Sarkar S (2013) Probiotics as functional foods: gut colonization and safety concerns. Nutr Fd Sci 43(5): 496-504.

6. Sanders ME, Marco ML (2010) Food formats for effective delivery of probiotics. Annual Rev Fd Sci Technol 1: 65-85.

7. Amin T, Thakur M, Jain S (2013) Microencapsulation-the future of probiotic cultures. J Microbiol Biotechnol Fd Sci 3: 35-43.

8. Granato D, Branco GF, Nazzaro F, Cruz AG, Faria JA (2010) Functional foods and nondairy probiotic food development: trends, concepts, and products. Compreh Rev Fd Sci Fd Safety 9(3): 292-302.
9. Li XY, Chen XG, Sun ZW, Park HJ, Cha DS (2011) Preparation of alginate/ chitosan/carboxymethyl chitosan complex microcapsules and application in Lactobacillus casei ATCC 393. Carbohydr Polym 83(4): 1479-1485.

10. Burgain J, Gaian C, Linder M, Scher J (2011) Encapsulation of probiotic living cells: From laboratory scale to industrial applications. J Fd Engin 104(4): 467-483.

11. Huertas RAP (2010) Revista facultad nacional deagronomía, medellín. Revisión: Microencapsulación de Alimentos 63(2): 5669-5684.

12. Vos PD, Faas MM, Spasojevic M, Sikkema J (2010) Encapsulation for preservation of functionality and targeted delivery of bioactive food components. Int Dairy J 20(4): 292-302.

13. Desai KG, Park HJ (2005) Recent developments in microencapsulation of food ingredients. Drying Technol 23(7): 1361-1394.

14. Giulio DB, Romero R, Amogan HP, Kusanovic JP, Bik EM, et al. (2008) Microbial prevalence, diversity and abundance in amniotic fluid during preterm labor: a molecular and culture-based investigation. PLoS ONE 3: e3056.

15. Rotimi VO, Duerden B (1981) The development of the bacterial flora in normal neonates. J Med Microbiol 14(1): 51-62.

16. Bello MGD, Costello EK, Contreras M, Magris M, Hidalgo G, et al. (2010) Delivery mode shapes the acquisition and structure of the initial microbiota across multiple body habitats in newborns. Proc Nat Aca Sci 107(26): 11971-11975.

17. Carlisle EM, Morowitz MM (2013) The intestinal microbiome and necrotizing enterocolitis. Curr Opin Pediatr 25(3): 382-387.

18. Biedermann L, Rogler G (2015) The intestinal microbiota: its role in health and disease. Eur J Pediat 174(2): 151-167.

19. Palop CN, Narbad A (2011) Probiotic assessment of Enterococcus faecalis $\mathrm{CP}_{5} 8$ isolated from human gut. Int J Fd Microbiol 145(2-3): 390-394.

20. FAO/WHO (2001) Regulatory and clinical aspects of dairy probiotics. Food and Agriculture Organization of the United Nations, World Health Organization Cordoba, Argentina.

21. Iannitti T, Palmieri B (2010) Therapeutical use of probiotic formulations in clinical practice. Clin Nutr 29(6): 701-725.

22. Kechagia M, Basoulis D, Konstantopoulou S, Dimitriadi D, Gyftopoulou K, et al. (2013) Health benefits of probiotics: a review. ISRN Nutr p. 481651.

23. Shi LH, Balakrishnan K, Thiagarajah K, Ismail NIM, Yin OS (2016) Beneficial properties of probiotics. Trop Life Sci Res 27(2): 73-90.

24. Prasanna PHP, Grandison AS, Charalampopoulos D (2014) Bifidobacteria in milk products: An overview of physiological and biochemical properties, exopolysaccharides production, selection criteria of milk products and health benefits. Fd Res Int 55: 247-262.

25. Kołodziej M, Szajewska H (2017) Lactobacillus reuteri DSM 17938 in the prevention of antibiotic associated diarrhoea in children: protocol of a randomised controlled trial. BMJ Open 7(1): e013928.

26. Kobyliak N, Conte C, Cammarota G, Haley AP, Styriak I, etal. (2016) Probiotics in prevention and treatment of obesity: a critical view. Nutr Metabol 13: 14.

27. Rolfe RD (2000) The role of probiotic cultures in the control of gastrointestinal health. J Nutr 130: 396-402.

28. Divya JB, Varsha KK, Nampoothiri KM, Ismail B, Pandey A (2012) Probiotic fermented foods for health benefits. Eng Life Sci 12(4): 377390.

29. Chavarri M, Maraonn I, Ares R, Ibanez FC, Marzo F, et al. (2010) Microencapsulation of a probiotic and prebiotic in alginate-chitosan capsules improves survival in simulated gastro-intestinal conditions. Int J Fd Microbiol 142(1-2): 185-189. 
30. Champagne CP, Ross PR, Saarela M, Hansen KF, Charalampopoulos D (2011) Recommendations for the viability assessment of probiotics as concentrated cultures and in food matrices. Int J Fd Microbiol 149(3): 185-193.

31. Tripathi MK, Giri SK (2014) Probiotic functional foods: survival of probiotics during processing and storage. J Funct Fds 9: 225-241.

32. Karimi R, Mortazavian AM, Cruz AG (2011) Viability of probiotic microorganisms in cheese during production and storage: A review. Dairy Sci Technol 91: 283-308.

33. Tyagi V, Kaushik SC, Tyagi SK (2011) Development of phase change materials based microencapsulated technology for buildings: A Review. Renewable Sustainable Ener Rev 15(2): 1373-1391.

34. Tontul AS, Erbaş M (2017) Single and double layered microencapsulation of probiotics by spray drying and spray chilling. LWT Fd Sci Technol 81: 160-169.

35. Fu N, Chen XD (2011) Towards a maximal cell survival in convective thermal drying processes. Fd Res Int 44(5): 1127-1149.

36. Huang S, Vignolles ML, Loir XDCY, Jan G, Schuck P, et al. (2017) Spray drying of probiotics and other food-grade bacteria: A review. Trends Fd Sci Technol 63: 1-17.

37. Kailasapathy K (2002) Microencapsulation of probiotic bacteria: technology and potential applications. Curr Iss Intest Microbiol 3(2): 39-48.

38. Picot A, Lacroix C (2004) Encapsulation of bifidobacteria in whey protein-based microcapsules and survival in simulated gastrointestinal conditions and in yoghurt. Int Dairy J 14(6): 505-515.

39. Petrovic T, Nedovic V, Brankovic SD, Bugarski B, Lacroix C (2007) Protection of probiotic microorganism by microencapsulation. CI\&CEQ 13: 169-174.

40. Pandey KR, Vakil BV (2017) Encapsulation of probiotic Bacillus coagulans for enhanced shelf life. J Appl Biol Biotechnol 5: 57-65.

41. Ciurzynska A, Lenart A (2011) Freeze-Drying - Application in Food Processing and Biotechnology-a Review. Pol J Fd Nutr Sci 61: 165-171.

42. Anekella K, Orsat V (2013) Optimization of microencapsulation of probiotics in raspberry juice by spray drying. LWT-Fd Sci Technol 50(1): 17-24.

43. Wisniewski R (2015) Spray drying technology review. $45^{\text {th }}$ International Conference on Environmental Systems, Bellevue, 12-16 July 2015. Washington, USA.

44. Leslie SB, Israeli E, Lighthart B, Crowe JH, Crowe LM (1995) Trehalose and sucrose protect both membranes and proteins in intact bacteria during drying. Appl Environ Microbiol 61(10): 3592-3597.

45. Corcoran B, Stanton C, Miao S, Fitzgerald GE, Ross RP (2006) Viability of probiotic bacteria as affected by drying. In: Buera PM, Chanes JW, Lillford PJ, (Eds.), Water Properties of Food, Pharmaceutical, and Biological Materials. $13^{\text {th }}$ Chapter, Taylor \& Francis Group, UK, pp. 1-8.

46. Knorr D (1998) Technology aspects related to microorganisms in functional foods. Trends Fd Sci Technol 9: 295-306.

47. Gardiner GE, Sullivan EO, Kelly J, Auty MA, Fitzgerald GF, et al. (2000) Comparative survival rates of human-derived probiotic Lactobacillus paracasei and L. salivarius strains during heat treatment and spray drying. Appl Environ Microbiol 66(6): 2605-2612.

48. Zuidam NJ, Shimoni E (2010) Overview of microencapsulates for use in food products or processes and methods to make them. In: Encapsulation technologies for active food ingredients and food processing, Springer Science+ Business Media, Dordrecht, Netherlands, pp. 122-135.

49. Serna L, Castillo VEV (2013) Probiotic encapsulation. Af J Microbiol Res $7(40): 4743-4753$.
50. Yudiastuti S, Sukarminah E, Mardawati E, Kastaman R (2019) Evaluation study of Lactobacillus acidophilus drying. IOP Conference Series: Earth and Environmental Science Volume 250.

51. Assadpour E, Jafari SM (2019) Advances in spray-drying encapsulation of food bioactive ingredients: From microcapsules to nanocapsules. Annual Rev Fd Sci Technol 10: 103-131.

52. Rokka S, Rantamaki P (2010) Protecting probiotic bacteria by microencapsulation: challenges for industrial applications. Europ Fd Res Technol 231(1): 1-12.

53. Silva PT, Fries LLM, Menezes CR, Holkem AT, Schwan CL, et al. (2014) Microencapsulation: Concepts, mechanisms, methods and some applications in food technology. Ciencia Rural 44(7): 1304-1311.

54. Martin JM, Villoslada FL, Ruiz MA, Morales ME (2015) Microencapsulation of bacteria: a review of different technologies and their impact on the probiotic effects. Innov Fd Sci Emerg Technologies 27: 15-25.

55. Shishir MRI, Chen W (2017) Trends of spray drying: A critical review on drying of fruit and vegetable juices. Trends Fd Sci Technol 65: 49-67.

56. Schafroth N, Arpagaus C, Jadhav UY, Makne S, Douroumis D (2012) Nano and microparticle engineering of water insoluble drugs using a novel spray-drying process. Colloids Surfaces B: Biointerfaces 90: 8-15.

57. Broeckx G, Vandenheuve D, Claes IJJ, Lebeer S, Kiekensa F (2016) Drying techniques of probiotic bacteria as an important step towards the development of novel pharmabiotics. Int J Pharma 505(1-2): 303-318.

58. Bakry AM, Abbas S, Ali B, Majeed H, Abouelwafa MY, et al. (2016) Microencapsulation of oils: A comprehensive review of benefits, techniques, and applications. Comp Rev Fd Sci Fd Safety 15(1): 143182.

59. Simoes LS, Madalena DA, Pinheiro AC, Teixeira JA, Vicente AA, et al. (2017) Micro and nano bio-based delivery systems for food applications: In vitro behavior. Adv Colloid Interface Sci 243: 23-45.

60. Sultana A, Miyamoto A, Lan QH, Tanaka Y, Fushimi Y, et al. (2017) Microencapsulation of flavors by spray drying using Saccharomyces cerevisiae. J Fd Engin 199: 36-41.

61. Reinoso ZS, Osorio C, Herrera A (2017) Effect of microencapsulation by spray drying on cocoa aroma compounds and physicochemical characterisation of microencapsulates. Powder Technol 318: 110-119.

62. Masters K (2002) Spray drying in practice. Spray dry consult international. Charlottenlund, Denmark.

63. Phisut N (2012) Spray drying technique of fruit juice powder: Some factors influencing the properties of product. Int Fd Res J 19: 1297-1306.

64. Freire CBF, Prudencio ES, Amboni RDMC, Pinto SS, Murakami AN, et al. (2012) Microencapsulation of bifidobacteria by spray drying in the presence of probiotics. Fd Res Int 45(1): 306-312.

65. Carranza PH, Malo AL, Munguia MTJ (2014) Microencapsulation quality and efficiency of Lactobacillus casei by spray drying using maltodextrin and vegetable extracts. J Fd Res 3(1): 61-69.

66. Reyes SVA, Suarez FJG, Jimenez MT, Gonzalez MFS, Perez LAB (2014) Protection of $L$. rhamnosus by spray-drying using two prebiotics colloids to enhance the viability. Carbohydrate Polymers 102: 423-430.

67. Hernandez RIC, Parrilla EA, Mendoza JL, Rubio ARI, Rosa LA, et al. (2013) Structural stability and viability of microencapsulated probiotic bacteria: a review. Comp Rev Fd Sci Fd Safety 12(6): 614-628.

68. Mortazavian A, Razavi SH, Ehsani MR, Sohrabvandi S (2007) Principle’s and method of microencapsulation of probiotic microorganisms. Iranian J Biotechnol 5(1): 1-18.

69. Santivarangkna C, Kulozik U, Foerst P (2007) Inactivation mechanisms of lactic starter cultures preserved by drying processes. J Appl Microbiol 105(1): 1-13. 
70. Pispan S, Hewitt CJ, Stapley AGF (2013) Comparison of cell survival rates of $E$. coli $\mathrm{K} 12$ and L. acidophilus undergoing spray drying. Fd Bioproducts Process 91(4): 362-369.

71. Peighambardoust SH, Tafti AG, Hesari J (2011) Application of spray drying for preservation of lactic acid starter cultures: A Review. Trends Fd Sci Technol 22(5): 215-224.

72. Vesterlund S, Salminen K, Salminen S (2012) Water activity in dry foods containing live probiotic bacteria should be carefully considered: A case study with Lactobacillus rhamnosus GG in flaxseed. Int J Fd Microbiol 157(2): 319-321.

73. Perdana J, Bereschenko L, Fox MB, Kuperus JH, Kleerebezem M, et al. (2013) Dehydration and thermal inactivation of Lactobacillus plantarum WCFS1: Comparing single droplet drying to spray and freeze drying. Fd Res Int 54: 1351-1359.

74. Perdana J, Fox MB, Siwei C, Boom RM, Schutyser MAI (2014) Interactions between formulation and spray drying conditions related to survival of Lactobacillus plantarum WCFS1. Fd Res Int 56: 9-17.

75. Khem S, Bansal V, Small DM, May BK (2016) Comparative influence of pH and heat on whey protein isolate in protecting Lactobacillus plantarum A17 during spray drying. Fd Hydrocolloid 54(2): 162-169.

76. Zheng X, Fu N, Huang S, Jeantet R, Chen XD (2016) Exploring the protective effects of calcium-containing carrier against drying-induced cellular injuries of probiotics using single droplet drying technique. Food Res Int 90: 226-234.

77. Ying DY, Sun J, Sanguansri L, Weerakkody R, Augustin MA (2012) Enhanced survival of spray-dried microencapsulated Lactobacillus rhamnosus GG in the presence of glucose. J Fd Eng 109(3): 597-602.

78. Heidebach T, Forst P, Kulozik U (2012) Microencapsulation of probiotic cells for food applications. Crit Rev Fd Sci Nutr 52(4): 291-311.

79. Ranadheera CS, Evans CA, Adams MC, Baines SK (2015) Microencapulation of Lactobacillus acidophilus LA-5, Bifidobacterium animalis subsp. lactis BB- 12 and Propionibacterium jansenii 702 by spray drying in goast's milk. Small Rum Res 123(1): 155-159.

80. Nunes GL, Etchepare MA, Cichoski AJ, Zepka LQ Lopes JE, et al. (2017) Inulin, hi-maize, and trehalose as thermal protectants for increasing viability of Lactobacillus acidophilus encapsulated by spray drying. LWT Fd Sci Technol 89: 128-133.

81. Prisco A, Mauriello G (2016) Probiotication of foods: a focus on microencapsulation tool. Trends Fd Sci Technol 48: 27-39.

82. Rodrigues D, Sousa S, Santos TR, Silva JP, Lobo JS, et al. (2011) Influence of L-cysteine, oxygen and relative humidity upon survival throughout storage of probiotic bacteria in whey protein-based microcapsules. Int Dairy J 21(11): 869-876.

83. Liu H, Gong J, Chabot D, Miller SS, Cui SW, et al. (2016) Incorporation of polysaccharides into sodium caseinate-low melting point fat microparticles improves probiotic bacterial survival during simulated gastrointestinal digestion and storage. Fd Hydrocolloids 54: 328-337.

84. Trindade CSF, Grosso CR (2002) Microencapsulation of L. acidophilus (La-05) and B. lactis (Bb-12) and evaluation of their survival at the $\mathrm{pH}$ values of the stomach and in bile. J Microencap 19(4): 485-494.

85. Tanzina H, Avik K, Ruhul AK, Riedl B, Lacroix M (2013) Encapsulation of probiotic bacteria in biopolymeric system. Crit Rev Fd Sci Nutr 53(9): 909-916.

86. Teoh PL, Mirhosseini H, Mustafa S, Hussin ASM, Manap MYA (2011) Recent approaches in the development of encapsulated delivery systems for probiotics. Fd Biotechnol 25(1-4): 77-101.

87. Ivanovska TP, Tozi L, Kostoska MD, Geskovski N, Grozdanov A, et al. (2012) Microencapsulation of Lactobacillus casei in Chitosan-CaAlginate microparticles using spray-drying method. Macedonian J Chem Chemical Engin 31: 115-123.
88. Chavez BE, Ledeboer AM (2007) Drying of probiotics: optimization of formulation and process to enhance storage survival. Drying Technol 25(7-8): 1193-1201.

89. Farnworth ER, Champagne C (2010) Production of probiotic cultures and their incorporation into foods. In: Watson ER, Preedy VR (Eds.), Bioactive foods in promoting health. Academic, London, UK, pp. 3-17.

90. Krasaekoopt W, Bhandari B, Deeth H (2003) Evaluation of encapsulation techniques of probiotics for yoghurt. Int Dairy J 13(1): 3-13.

91. Iravani S, Korbekandi H, Mirmohammadi SV (2015) Technology and potential applications of probiotic encapsulation in fermented milk products. J Fd Sci Technol 52(8): 4679-4696.

92. Anal AK, Singh H (2007) Recent advances in microencapsulation of probiotics for industrial applications and targeted delivery. Trends Fd SciTechnol 18: 240-251.

93. Lee EY (2012) Effect of atomization on viability of microencapsulated probiotics. Food Science \& Human Nutrition.

94. Jantzen M, Gopel A, Beermann C (2013) Direct spray drying and microencapsulation of probiotic Lactobacillus reuteri from slurry fermentation with whey. J Appl Microbiol 115(4): 1029-1036.

95. Ivanovska TP, Tozi LP, Grozdanov A, Petkovska R, Hadjieva J, et al. (2014) From optimization of symbiotic microparticles prepared by spraydrying to development of new functional carrot juice. Chem Ind Chem Eng 20(4): 549-564.

96. Maciel GM, Chaves KS, Grosso CRF, Gigante ML (2014) Micro encapsulation of Lactobacillus acidophilus La-5 by spray-drying using sweet whey and skim milk as encapsulating materials. J Dairy Sci 97(4): 1991-1998.

97. Fazilah NF, Hamidon NH, Ariff AB, Khayat ME, Wasoh H, et al. (2019) Microencapsulation of Lactococcus lactis Gh1 with gum arabic and Synsepalum dulcificum via spray drying for potential inclusion in functional yogurt. Molecules 24(7): 1422

98. Malmo C, Storia A, Mauriello G (2011) Microencapsulation of Lactobacillus reuteri DSM 17938 cells coated in alginate beads with chitosan by spray drying to use as a probiotic cell in a chocolate soufflé. Fd Bioprocess Technol 6(3): 795-805.

99. Paez R, Lavari L, Vinderola G, Audero G, Cuatrin A, et al. (2012) Effect of heat treatment and spray drying on lactobacilli viability and resistance to simulated gastrointestinal digestion. Fd Res Int 48(2): 748-754.

100. Chaipojjana R, Phosuksirikul S, Leejeerajumnean A (2014) Survival of four probiotic strains in acid, bile salt and after spray drying. Int J Nutr Fd Engin 8(9): 1060-1063.

101. Piano M, Carmagnola S, Andorno S, Pagliarulo M, Tari R, et al. (2010) Evaluation of the intestinal colonization by microencapsulated probiotic bacteria in comparison with the same uncoated strains. I Clin Gastroenterol 44(Suppl 1): S42-46.

102. Burns P, Alard J, Hrdy J, Boutillier D, Paez R, et al. (2017) Spray-drying process preserves the protective capacity of a breast milk derived Bifidobacterium lactis strain on acute and chronic colitis in mice. Sci Rep 7: 43211.

103. Balamurugan R, Magne F, Balakrishnan D, Suau A, Ramani S, et al (2010) Faecal bifidobacteria in Indian neonates and the effect of asymptomatic rotavirus infection during the first month of life. Indian J Med Res 132(6): 721-727.

104. Benno Y, Sawada K, Mitsuoka T (1984) The intestinal microflora of infants: composition of fecal flora in breast-fed and bottle-fed infants. Microbiol Immunol 28(9): 975-986.

105. Biasucci G, Benenati B, Morelli L, Bessi E, Boehm G (2008) Cesarean delivery may affect the early biodiversity of intestinal bacteria. J Nutr 138(9): 1796-1800. 
106. Gewold IH, Schwalbe RS, Taciak VL, Harrisonn TS, Panigrahi P (1999) Stool microflora in extremely low birth weight infants. Arch Dis Child Fetal Neonatal Edu 80(3): 167-173.

107. Gronlund MM, Lehtonen OP, Eerola E, Kero P (1999) Fecal microflora in healthy infants born by different methods of delivery: permanent changes in intestinal flora after cesarean delivery. J Pediat Gastroenterol Nutr 28(1): 19-25.

108. Guemonde M, Sakata S, Kalliomaki M, Isolauri E, Benno Y, et al. (2006) Effect of maternal consumption of Lactobacillus GG on transfer and establishment of fecal bifidobacterial microbiota in neonates. J Pediat Gastroenterol Nutr 42(2): 166-170.

109. Harmsen HJM, Veloo ACMW, Raangs GC, Wagendorp AA, Klijn N, et al. (2000) Analysis of intestinal flora development in breast-fed and formula-fed infants by using molecular identification and detection methods. J Pediat Gastroenterol Nutr 30(1): 61-67.

110. Jakaitis BM, Denning PW (2014) Commensal and probiotic bacteria may prevent NEC by maturing intestinal host defenses. Pathophysiol 21(1): 47-54.

111. Patel RM, Denning PW (2013) Therapeutic use of prebiotics, probiotics and postbiotics to prevent necrotizing enterocolitis: what is the current evidence? Clin Perinatol 40(1): 11-25.

112. Penders J, Thijs C, Vink C, Stelma FF, Snijders B, et al. (2006) Factors influencing the composition of the intestinal microbiota in early infancy. Pediatrics 118(2): 511-521.

113. Rodriguez JM, Murphy K, Stanton C, Ross RP, Kober OI, et al. (2015) The composition of the gut microbiota throughout life, with an emphasis on early life. Microbial Ecol Hlth Dis 26: 26050.
114. Shanahan F (2002) The host-microbe interface within the gut. Best Prac Res Clin Gastroenterol 16(6): 915-931.

115. Steer T, Carpenter H, Touhy K, Gibson GR (2000) Prespectives on the role of the human gut microbiota and its modulation by pro- and probiotics. Nutr Res Rev 13(2): 229-254.

116. Stenger MR, Reber KM, Giannone PJ, Nankervis CA (2011) Probiotics and prebiotics for the prevention of necrotizing enterocolitis. Curr Infect Dis Rep 13(1): 13-20.

117. Sullivan GC, Kelly P, Halloram OS, Collins C, Collins JK, et al. (2005) Probiotics: An emerging therapy. Curr Pharm Design 11(1): 3-10.

118. Teoh PL, Mirhosseini H, Mustafa S, Hussin ASM, Manap MYA (2011) Recent approaches in the development of encapsulated delivery systems for probiotics. Fd Biotechnol 25(1): 77-101.

119. Valles Y, Artacho A, Garcia AP, Ferrus ML, Gosalbes MJ, et al. (2014) Microbial succession in the gut: directional trends of taxonomic and functional change in a birth cohort of Spanish infants. PLoS Genet 10(6): e1004406.

120. Vasiljevic T, Shah NP (2008) Review: probiotics-from Metchnikoff to bioactives. Int Dairy J 18(7): 714-728.

121. Yoshioka H, Iseki K, Fujita K (1983) Development and differences of intestinal flora in the neonatal period in breast-fed and bottle-fed infants. Pediatrics 72(3): 317-321.

122. Yuhara T, Isojima S, Tsuchiya F, Mitsuoka T (1983) On the intestinal flora of bottle-fed infants. Bifidobacteria Microflora 2(1): 33-39.

For possible submissions Click below:

Submit Article 